\title{
Current State and Prospects of Environmental Problems Legal Regulation in Coal Industry (on Example of Kemerovo Mining Region)
}

\author{
Marina Agienko ${ }^{1, *}$, Elena Moroz $^{1}$, and Alexandr Naumov ${ }^{1}$ \\ ${ }^{1}$ Plekhanov Russian University of Economics, 650992, Kuznetskiy Prospect, 39. Kemerovo, Russia
}

\begin{abstract}
The legal aspect of subsoil use in our country is one of the most controversial today. It requires its improvement to create the conditions for the transition to a sustainable economic development in our country. In addition, a comparative analysis of the legal documents of the Russian Federation in this area shows that there are obvious flaws in this issue for legislative purposes. The article assesses the state of legal interfacing in the field of mining (processing), the use of coal and coal products, and discusses the problems arising in this industry. Perspectives were identified and the need to develop special legislation in the coal sector, consistent with the norms of environmental, civil, labor and other branches of legislation was shown.
\end{abstract}

\section{Introduction}

The coal industry is one of the leading sectors of the fuel and energy complex. Coal is a strategically important raw material in the energy and industrial complexes, used not only in the domestic, but also in the international market. Russia, having significant coal resources of more than 4000 billion tons, ranks second in its reserves (19\% of world reserves), fifth place in terms of annual production ( $5 \%$ of world production) and provides about $12 \%$ of world trade with forge coal.

Kemerovo region is one of the largest industrial regions in Russia, which has a high economic potential. This region plays a crucial role in the economy not only of Siberia, but of all Russia. The economy of the region is based mainly on the coal industry and metallurgy. Industrial coal production accounts for more than $30 \%$ of the total production in the region and about $80 \%$ in Russia.

The current state of the world economy shows that it is the coal industry that falls into the top ten spheres that have the greatest impact on the economic potential of a country, but at the same time it has one of the most destructive impacts on the environment and the state of the ecosystem.

Today we can observe a significant increase in production in the coal industry, which naturally affects the environmental situation in the mining areas. On the part of the state, these works are governed by regulatory documents and acts. Regulation of industry in the

\footnotetext{
* Corresponding author: marinaivanovnaag@mail.ru
} 
field of mining (processing) and the use of coal are main policies of the region. But the legal regulation of relations arising in the coal industry is accompanied by certain problems caused by the current state of the regulatory legal framework in this area, which has a complex nature, as well as technical imperfection of production and social tensions associated with the difficulty of ensuring a high living standards of the miners.

\section{Materials and Methods}

The main environmental problem in increasing coal production is the deterioration of the human environment. The introduction of human activity in natural processes led to landscape changes, to air pollution and, as a result, depletion of biological and natural diversity. Negative consequences such as landscape disfigurement resulting from the dumping sites and sludge pits that is typical for the industrial sector in the region must be controlled not only at the regional, but also at the state level. To do this, it is necessary to ensure the compliance with the current legal requirements for environmental protection and to monitor enterprises engaged in mining of minerals.

A characteristic feature of the legal regulation of coal mining, processing and use of coal is the formation of special industry legislation, the adoption of which is predetermined, first of all, by the importance of coal and coal industry for the development of the Russian economy. Selected measures should be aimed primarily at the integrated and highly rational use of minerals and natural resources [1].

Coal-processing and mining companies must ensure the full implementation of the standards and requirements established by law, as well as the requirements contained in environmentally related industries established by the legislation of the Russian Federation on the use of natural and water resources. At the same time, this industry requires solving a number of environmental problems that accompany it. Among them are the following:

- features of the chemical composition of coal produced;

- technological features of the methods and techniques used in coal mining;

- methods of enrichment and use of deposits.

The reform of the coal industry, accompanied by the restructuring of the industry, objectively required the adoption of a special legislative act aimed at regulating public relations in the field of coal mining and use. The legal basis for their regulation was laid down by the Federal Law "On State Regulation in the Field of Coal Mining and Use, and on Peculiarities of Social Protection of Coal Industry Organizations".

The coal industry is determined by the following principles as a result of the implementation of the state program:

- priority of human security and ecology

- mandatory state regulation of rules and regulations for the safe conduct of coal mining

- creation of safe and healthy working conditions at the workplace, ensuring safe management of technological processes for coal mining and processing.

Moreover, lately, the problem of the main production process related to the opencast mining of coal deposits has become increasingly acute at the stage of determining the coal mining sites and determining the licensing requirements for mining. The acuteness of the problem stems from the fact that there is still no approved coal mining program in the Kemerovo Region. Another problem is related to the lack of coordination between the federal center (Rosnedra) and the regional administration in the process of issuing coal mining licenses.

Of course, the Federal Agency on Subsoil Usage ("Rosnedra") does not start licencing precedure if there are no persons interested in developing the site but as a result land is put up for auction without taking into account social and environmental issues. Scientists believe that the country needs a transition from the declarative principle of licensing to the 
programmed one. At the same time, it is worth considering whether it is necessary to mine coal in such volumes (in 2018, 255.3 million tons were mined in the Kemerovo region). With the money received from the sale of coal, the owners acquire the latest technology to mine and sell even more and we have ever repeated circle - the more we mine, the more serious the ecological problems get!.

The Kemerovo Region is known to have long been balancing on the verge of overproducing coal, in terms of volume (according to experts, it is critically dangerous to exceed production over 220 million tons per year). The natural question arises: "What will become of the region and our "coal cities" after the resource potential has been exhausted?" The assessment of the potential of natural resources has established that existing enterprises are provided with coal, which can be mined only for a certain period: 47 years for mines, and 30 years for cuts. Hence the conclusion is: along with the solution to the problems of coal mining planning and limiting it near settlements throughout the Kemerovo region, it would be logical to shape the non-resource future of the region at the expense of revenues from the sale of coal rather than leaving the moonscape of coal seams and an endless sea of social problems (including public health).

Apparently, it is cheaper to extract coal by an open method, and the location of open-pit mines near settlements allows significant savings on infrastructure. However, we cannot justify the situation only with the benefit of the coal companies - it reduces attention to the fulfillment of environmental obligations, compliance with laws and the provision of social obligations. Recently coal miners are developing more and more new territories of the Kemerovo region, often affecting the interests of rural residents and not reckoning with them. A conflict of interest arose especially with the government resolution allowed the withdrawal of private land for the extraction of coal for state needs. It turns out an incident: the state infringes the rights of one private trader in favor of another.

At the same time, there are no contradictions between federal laws, but there is a clear violation of Article 42 of the Constitution of the Russian Federation [1], according to which every citizen has the right to a favorable environment and Article 209 of the Civil Code on the right of private land ownership is also violated [2-4]. This situation can be resolved, according to environmentalists and law enforcement agencies, but in order to satisfy the interests of both interested sides, a regional coal-mining program must be developed.

\section{Results and Discussion}

Despite the fact that the scope of regulation by the Federal Law of the Russian Federation No. 81-FZ [5] includes coal mining, there are no reference standards for natural resources, as well as other environmental legislation. At the same time, it should be noted that there are important problems that have not been resolved at the state level to date.

Federal Law No. 81-FZ is limited only by reservations about the priority of environmental safety as an integral part of the fundamental principles of ensuring labor safety with coal [5].

As noted in the state-approved subprogram "Ensuring technological development of industry and strengthening the scientific and technical base of the enterprise and scientific centers", within the framework of the state program for the development of the coal industry for the period up to 2030, in the industrial sector along with non-traditional coal mining methods are planned:

- improvement of existing technologies and the introduction of more modern technological solutions in the process of underground coal gasification;

- improvement of technological processes for obtaining liquid fuel from coal without changing the physical state of coal as a natural product.

Transformations in the coal industry in the process of restructuring necessitate a review 
of the current legislation in the field of mining (processing) and the use of coal, based on the need to ensure a balance of private-law and public law principles in regulating these relations using positive foreign experience. This requirement applies primarily to Federal Law $\mathrm{N}$ 81-Ф3, the legal norms of which, moreover, require coordination with environmental, natural resource and other legislation. In fact, it is about the development of a new law regulating relations arising in the coal industry. For this, it is necessary to determine the legal definition of this concept.

Coal companies operating in the coal market supply coal and its products to consumers on the basis of long-term contracts made in accordance with the Civil Code of the Russian Federation. Federal Law No. 81 stipulates that the Government of the Russian Federation may establish standard terms for long-term coal supply contracts through the federal executive authorities (ministries). However, up to the present date, such conditions in the Ministry of Energy of Russia have not been approved, or registered with the Ministry of Justice and have not been published and, therefore, this document does not meet the formal criteria of a regulatory act. This situation causes uncertainty in practice.

There are also gaps in the legal regulation of contracts for the supply of coal and coal products for state and municipal needs. Paragraph 3 of Art. 11 of the Federal Law N 81-FZ contains a blanket rule providing for the determination of the procedure for concluding and agreeing by the relevant federal law the terms of contracts for the supply of coal and its products for public use. Firstly, this provision wrongfully limits such agreements to government needs (there are also the municipal needs - housing and communal services, social services, household needs of the population). Secondly, the regulatory legal framework for contractual relations for the supply of coal and coal products is not limited to one federal law. Today, the approval of the terms of contracts for the supply of coal and its products for state and municipal needs is carried out in accordance with the procedure established by the Federal Law of April 5, 2013 N 44-FZ "On the contract system in the field of procurement of goods, works and services for state and municipal needs "[4].

As the analysis of Federal Law N 81-FZ shows, its norms lack a number of positions agreed with the adjacent legislation that reinforce the requirements and determine the specifics of regulation of relations in the field of mining (processing) and the use of coal and coal products.

Among them are antitrust requirements. In recent years, as a result of the restructuring of the coal industry, private coal companies have been consolidated, and most of them have been transferred to the structures of large metallurgical or energy holdings and corporations that consume coal as coke or fuel. Coal companies, whose share in the coal market is more than $35 \%$, are subject to competition law and are subject to inclusion in the Register of economic entities maintained by the Federal Antimonopoly Service (FAS Russia). In addition, at the initiative of the FAS Russia, coking coal, stone, brown and anthracite are included in the list of goods for which all off-exchange trades, including supply agreements, must be registered by the commodity exchange under certain conditions.

Despite the fact that the scope of regulation of Federal Law N 81-FZ includes coal mining, it does not contain reference norms to the legislation on mineral resources [3], as well as to other natural resource legislation. Thus, in the process of coal mining, the requirements are stipulated not only by the legislation on the subsoil, but also by the water legislation. As an example, the discharging of drainage water into water bodies, must be observed.

In turn, some specific features associated with coal mining remain unresolved in the natural resource legislation. For example, in the Water Code of the Russian Federation there are no norms defining the order of collection and discharge into water bodies of mine and mine waters, which are underground or surface waters, penetrating into the stopes, quarries of coal and mine deposits and having a negative impact on the conditions of 
opening and exploitation of deposits mineral. Coal mining companies at the stages of exploration and production of coal are subject to licensing and other powers of the Federal Subsoil Use Agency (Rosnedra), which performs the functions of providing public services and managing state property in the area of subsoil use.

The Program for the Development of the Coal Industry of Russia for the period until 2030, approved by Decree of the Government of the Russian Federation of June 21, $2014 \mathrm{~N}$ 1099-p [6] indicates the need to create a system for managing industrial safety and labor protection in order to reduce the level of industrial injuries. This task is implemented both at the corporate and at the government level. State supervision over the safe conduct of mining (processing) of coal, which is an integral part of state mining supervision, is carried out by The Federal Service for Environmental, Technological, and Nuclear Supervision (Rostechnadzor). Its authority is to oversee the safe conduct of operations related to the use of subsoil, compliance with fire safety requirements in underground facilities and blasting operations.

This federal executive body, which also performs the functions of implementing state policy and legal regulation in the established field of activity, has adopted a large number of regulatory legal acts in the field of coal industry safety. Rostechnadzor's Orders are sent to ensure industrial safety of the coal industry. They are

"On Approval of Federal Norms and Rules in the Field of Industrial Safety "Instructions for Combating Dust in Coal Mines" of October 14, 2014 N 462,

"On Approval of Federal norms and rules in the field of industrial safety "Safety rules in coal mines" of November 19, 2013 N 550

"On Approval of instructions for drawing up plans for emergency response in coal mines" dated December 1, 2011 N 681,

"On Approval of the Regulation on Aerogas Control in Coal Mines" dated December 1, 2011 N 678 and others [7].

Conducting rescue operations in the coal industry is carried out in accordance with the provisions of Federal Law No. 81-FZ, providing emergency rescue services to organizations for the extraction (processing) of coal (oil shale) (art. 16), as well as their creation of auxiliary mountain rescue teams (art.16.2) in the manner approved by the Order of the Ministry of Emergency Situations of Russia of November 29, 2013 N 765 [8].

Along with industrial safety, environmental protection and safety must be ensured during processing of and the uses of coal and coal products. The environmental protection and safety subprogram "Ensuring environmental safety" of the Program for the Development of the Coal Industry of Russia for the Period up to 2030 is aimed at creating conditions for reducing the negative environmental impact of the industrial activities of coal industry facilities. One of the key conditions for its implementation is the improvement of legislation in the coal sector, aimed at ensuring environmental protection, environmental and industrial safety, which requires a theoretical and legal understanding of the issues discussed in the legal doctrine about the relationship between these concepts.

In the meantime, only half-hearted decisions are made on the type of: "when the fire is on, we put it out!". So, in order to implement the provisions of the state policy framework in the field of environmental development of the Russian Federation [6], the specialists of the Federal Research Center for Coal and Coal Chemistry of the Siberian Branch of the Russian Academy of Sciences and the Kemerovo Regional Environmental Organization "Irbis" developed guidelines [9]:

- on the use of the integral indicator of the suitability of disturbed lands for the reclamation of the coal industry dumps;

- on forest reclamation of disturbed lands at coal industry enterprises in the Kemerovo Region;

- on the restoration of meadow-steppe flora on the dumps of the coal industry in the 
Kemerovo region.

The listed recommendations are approved and recommended for application and management of the coal industry organizations operating in the Kemerovo region by order of the collegium of the administration of the Kemerovo region dated 10.08.2017 No. 357-p.

Meanwhile, the prosecutor's office of the Kemerovo region records the facts when enterprises "go bankrupt" before recultivation of disturbed lands and thereby withdraw from the land reclamation obligations. In this case the land is transferred to the municipality, which, of course, has no funds for reclamation. Therefore, all "lunar landscapes", of which there is a huge amount in the Kemerovo region, are exclusively problems of legislation [11].

This would not have happened if the insurance liability procedure had been ensured, that is, if funds had been withdrawn in advance during the procedure for issuing permits for the use (violation of integrity) of lands for the purpose of extracting mineral resources. This would be a guarantee that they were used in a timely manner, in a targeted manner, to carry out land reclamation and to solve the social problems of the population in the industrial use zone of these lands [10]. And just a very serious problem of the Kemerovo region is a rather extensive fund of disturbed lands, which require recultivation and transfer them to another category of lands.

In the use of land and mineral resources in the Kemerovo region, there are many types of environmental offenses, for which the legislation has clearly defined the types of liability applicable to an environmental offense. However, the actual application of legal liability for environmental offenses is due to the fact that the norms of environmental legislation are reference ones and provide in most cases only a list of offenses applicable to individual natural resources. As for specific sanctions, their application has been established in other branches of the law: (criminal, administrative, civil and others).

As the discussion of problems at the environmental forum in KemSU (11/17/2017) showed that despite a lot of documents, meetings and ecological events with considerable investment, environmental problems are not always the basis of the socio-economic development strategy.

Since both the monitoring of the implementation of legislation, and especially the analysis of the state of the environment in the Kemerovo region, as follows from the reports of the prosecutor's office, the All-Russian People's Front, the Departments of People's Resources and Forestry Complex of the Kemerovo Region Administration, the Federal Oversight Service for Consumers' Rights and Human Welfare (Rospotrebnadzor) in the Kemerovo Region and the residents of industrialized territories, need more thorough implementation, the state and protection of water, air, land and the forest is the most alarming.

We considered only some pressure points which are the most acute environmental problems, primarily from the standpoint of compliance with Russian and local (regional) legislation. We believe that it is necessary to streamline legislation and law enforcement activities aimed at respecting the rule of law at all stages of using the natural resources of the Kemerovo region, both in order to preserve the natural environment (and not lead it to full exhaustion) and ensure a decent quality of life for its people. And here everything should be based on activities aimed at preventing possible risks and complications.

Improvement measures which are absolutely necessary in all territories of the region, unfortunately, often only create the appearance of great attention to the comfortable life of the urban residents and villagers, but generally speaking they do not solve the problems of improving the environmental situation in the region, especially those located near large mining and processing enterprises, which are the main sources of enormous pollution of the natural environment, and therefore violating the very foundations of human life and activity mandated by the Constitution of the Russian Federation. 


\section{Conclusion}

Thus, the constantly growing rates of coal mining in the Kemerovo Region and in Russia as a whole lead to the development of an environmental and social disaster in the region. Unfortunately, the prevailing part of the legal acts regulating the activities of industrial production in the Kemerovo Region and in Russia in general do not provide for the guarantees in the case of harm to nature and in those documents that contain provisions on the use of insurance to compensate for any harm that occurs and there are no implementation mechanisms of that kind.

At present, the state legal regulation of relations arising in the coal industry is not limited to the problems outlined. The improvement of the legal mechanism in this area should be carried out based on a systematic approach that ensures the functional interaction of the norms of energy, environmental and other branches of legislation, their balanced correlation and interrelation. The final stage of the coal industry restructuring is underway and it will be completed by the end of 2020, in accordance with the results of which it will turn from a planning-unprofitable to an effectively functioning industry.

\section{References}

1. The Constitution of the Russian Federation (adopted by popular vote on 12.12.1993) (Russian Newspaper, 1993)

2. Civil Code of the Russian Federation (Russian Newspaper, Moscow, 2015)

3. Law of the Russian Federation of 21.02.1992 N 2395-1 (Russian Newspaper, 1993)

4. Federal Law "On the contract system in the field of procurement of goods, works, services for state and municipal needs" dated 05.04.2013 N 44-FZ (Russian Newspaper, Moscow, 2013)

5. Federal Law "On State Regulation in the Field of Coal Mining and Use, on Peculiarities of Social Protection of Coal Industry Organizations" dated June 20, 1996 N 81-FZ (Russian Newspaper, Moscow, 1996)

6. Fundamentals of state policy in the field of environmental development of the Russian Federation for the period up to 2030 (Russian Newspaper, Moscow, 2015)

7. Order dated December 1, 2011 No. 678 "On approval of the Regulation on aerogas control in coal mines” (Russian Newspaper, Moscow, 2011).

8. Order EMERCOM of Russia of November 29, $2013 \mathrm{~N} 765$ "On approval of the procedure for creating auxiliary mine-rescue teams" (Russian Newspaper, Moscow, 2013)

9. About methodical recommendations on recultivation of disturbed lands. Order of the collegium of the administration of the Kemerovo region of 10.08.2017 No. 357-p. (Russian Newspaper, Moscow, 2017)

10. M. Agienko, A. Naumov, I. Gaag, Yu. Volgin, Conf. Ser.: Mater. Sci. Eng., 41, 04046 (2018)

11. V. Shelestukov, V. Erin, G. Pavlov, Conf. Ser.: Mater. Sci. Eng., 41, 02029 (2018) 